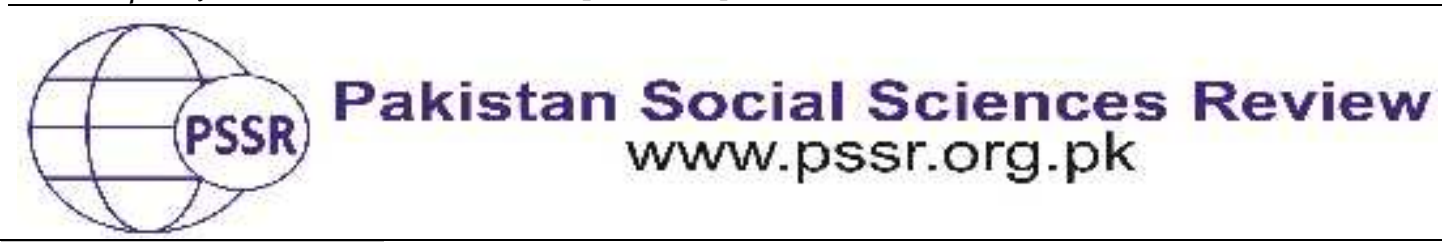

RESEARCH PAPER

\title{
Intrinsic Motivation and Extrinsic Motivation as the Factors involved in English Learning in District Bannu
}

Dr. Abdul Karim Khan ${ }^{1}$ Dr. Abdus Samad ${ }^{2}$ Dr. Ihsan Ullah Khan ${ }^{3}$

1. Assistant Professor Department of English UST Bannu, KP, Pakistan

2. Assistant Professor/Chairman, Department of English KUST, Kohat, KP, Pakistan

3. Assistant Professor Department of English UST Bannu, KP, Pakistan

\begin{tabular}{|c|c|}
\hline PAPER INFO & ABSTRACT \\
\hline $\begin{array}{l}\text { Received: } \\
\text { March 24, } 2021 \\
\text { Accepted: } \\
\text { May 01, } 2021 \\
\text { Online: } \\
\text { May 15, } 2021\end{array}$ & $\begin{array}{l}\text { This research paper mainly deals with investigating the } \\
\text { involvement of the Extrinsic Motivation as factor in English } \\
\text { learning at intermediate level students of government degree } \\
\text { colleges in Bannu (KPK). A lot of factors are involved in the } \\
\text { learning of English but here only the factors of intrinsic }\end{array}$ \\
\hline $\begin{array}{l}\text { Keywords: } \\
\text { Bannu, } \\
\text { Intrinsic Motivation, } \\
\text { Extrinsic Motivation, } \\
\text { English Learning } \\
\end{array}$ & $\begin{array}{l}\text { motivation and extrinsic motivation were selected tor the study. } \\
\text { The approach of the research is explorative. Primary facts were } \\
\text { collected from the five degree colleges which are located in } \\
\text { District Bannu. Out of the } 300 \text { students one hundred students } \\
\text { were selected as sample through following L.R. Gay's model }\end{array}$ \\
\hline $\begin{array}{l}\text { *Corresponding } \\
\text { Author }\end{array}$ & $\begin{array}{l}\text { criteria. The primary data was collected and analyzed through } \\
\text { close-ended Likert agreement scale questionnaire, and } \\
\text { interpreted through tables Exploded Pi-Charts and 3-D } \\
\text { Columns. It was found that the factor of extrinsic motivation has } \\
\text { the main role in the learning of English at the mentioned level. }\end{array}$ \\
\hline $\begin{array}{l}\text { Dr.Samad@Kust. } \\
\text { edu.pk }\end{array}$ & $\begin{array}{l}\text { The scholar found that the majority of the students were less } \\
\text { motivated both intrinsically and extrinsically. }\end{array}$ \\
\hline
\end{tabular}

\section{Introduction}

English is an international language and its importance cannot be denied that is why its learning is crucial in this fast progressing world. At the same time, it is also notable that while learning English many obstacles are faced by the learners as well as the teachers. In this regard, various factors involved, both cognitive and social, in the complex phenomenon of Language learning. Personality, motivation, experience, cognition as well as aptitude are the cognitive factors involved in English learning include. While curriculum, teaching instruction, culture and access to native speakers are the social factors involved in the learning of English. The complex interplay of these factors determines the performance of the English language learners. 
The researcher in the present study has chosen the factors of intrinsic and extrinsic motivation as they are interrelated. Intrinsic motivation and extrinsic motivation, the two prominent types of motivation, fall under the cognitive factors. A far as the interrelationship of these types of motivation is concerned, the one enhances the other and vice versa. For instance, when the language teacher tries to motivate the learners and they show good results, the teacher feels encouraged and motivated. Thus the teacher will give more attention to the learners and the process of English learning will move on to success.

The scholars have chosen the intermediate level for the present study because all the students study English as a compulsory subject at this level. Moreover, the students at this level are familiar with the basics of grammar, thus they understand the statements in the questionnaire. In addition, the scholar has personal experience of teaching at the intermediate level for two years, and it was during these years that the scholars felt the utmost need to conduct research on the various factors involved in the English learning process. The researchers have chosen colleges for males as it is difficult to collect the primary data from girls' colleges because of cultural impediments. Moreover, the teachers at the boys' colleges are easily accessible and more cooperative as regards data collection.

This study is an effort to examine the extent of involvement of the mentioned factors in the process of English learning of the intermediate level English learners of Government Degree Colleges for boys in District Bannu. There are five degree colleges for boys in Bannu District. These colleges are: Government Degree College Bannu, Government Degree College Ghoriwala Bannu, Government Degree College Domel, Government Degree College Sikandar Khel Bala Bannu and Government Degree College Kakki Bannu.

The scholars have chosen the intermediate level for this study. Intermediate is the level in which all the students read and learn English as a compulsory subject. Furthermore, the students at the intermediate level are familiar with the basics of grammar; therefore they understand the statements in the questionnaire. Moreover, the researchers have personal experience of teaching English at the intermediate level for two years, and it was during these years that the scholar felt the utmost need to conduct research on the various factors involved in the English learning process. The researchers have chosen the male colleges as it was difficult to collect the primary data from girls' colleges because of cultural impediments.

There are various cognitive and social factors involved in the process of English learning. Learning of a language depends upon the learners' age, personalities, self-esteem, as well as motivation. Furthermore, teaching methodology, the learners and friendly interaction between the teacher, and culture are the important social factors that make or break an English language class. Besides the above mentioned factors, there are some other factors which are necessary to be taken into consideration with reference to District Bannu. The researchers in the present study have chosen the factors of intrinsic and extrinsic motivation as they are interrelated. Intrinsic motivation and extrinsic motivation, the 
two prominent types of motivation, fall under the cognitive factors. A far as the interrelationship of these types of motivation is concerned, the one enhances the other and vice versa. For instance, when the language teacher tries to motivate the learners and they show good results, the teacher feels encouraged and motivated. Thus the teacher will give more attention to the learners and the process of English learning will move on to success.

\section{Literature Review}

Much research is done by various linguists and experts on English. Here in this review of literature the researcher will briefly explain the concept of second language acquisition and then will discuss the various social and cognitive factors influencing the process of language acquisition.

Nativist and Emergenist are the two types of SLA models that try to explain the process of SLA. According to Nativist models second language learning of grammar proceeds in accordance with the principles of Universal Grammar (Chomsky, 1965). On the other hand, Emergentist models, such as the Competition Model hold that grammar learning is based on an interaction between the input, the context and the learner understandable input is another factor that influences SLA(MacWhinney, 2001).

In order to expedite the SLA process, Krashen (1981) says that understandable input enhances second language acquisition. He maintains that grammatical sequencing of input is not necessary rather it hampers the smooth learning process. However, Long (1996) does not accept Krashen's Input Hypothesis. He asserts that only input is not sufficient to explain SLA. Krashen is apt to say that grammatical sequencing disturbs the learning process, but he neglects the fact that avoiding such sequencing mars accuracy.

Apart from the modifications in interaction found in SLA, Egger (1987) maintains that communicative activities provide "meaningful creative context that encourage students to use language that says what they want it to say, as well as to speak without considerable hesitation and faltering."Egger stresses on the factor of positive reinforcement on part of the language teachers/peers. This creates a friendly environment and the learner feels relaxed. Similarly, Awan (2008) considers fear and hesitation as the greatest obstacles in the way of language learning mechanism.

Moreover, Hussain et al (2001) quoting Oxford says that there are six factors that impact motivation in second language acquisition. These factors are: Learner's Attitudes; Learner's beliefs about self; Goals; Learner's Involvement; Environmental Support (support from peers and teachers); and learner's Personal Attributes. 


\section{Intrinsic Motivation}

The term 'motivation' in general refers to a person's urge or drive for something to do. It is defined by the Oxford English Dictionary (1989) as "the general desire or willingness of someone to do something". In connection to language learning, Motivation, according to Gardner (1985), refers "to the extent to which the individual works or strives to learn the language because of a desire to do so and the satisfaction experienced in this activity."

In addition, Educational psychology classifies motivation into two types intrinsic and extrinsic. Intrinsic motivation refers to the learner's desire to learn. It is learning for enjoyment. Here learning becomes a fun. On the other hand, extrinsic motivation is motivation to perform and succeed for the sake of accomplishing a specific result or outcome (Davis, 1993). Extrinsically motivated students are gradeoriented, whereas intrinsically motivated students are genuinely interested in their work.

As far as the role of motivation in SLA is concerned, it was Robert Gardner and Wallace Lambert who for the first time conducted their research on attitudes and motivation in SLA in 1959. They consider motivation as an important factor in the process of SLA. Moreover, Gardner (1982) took insight for his socio-education model from Mowrer (1950, quoted in Larson-Freeman and Long 1994), who focuses on FLA. Gardner makes it the basis for investigating motivation as an effective factor in SLA.

Gardner (1982) asserts that many factors are involved in SLA. His socioeducation model interrelates the four features of SLA, i.e. individual differences; linguistic outcomes; the context in which learning occurs; the cultural and social milieu. Giles and Coupland (1991) explain that Gardner's model in its second phase mentions the four individual differences including motivation, anxiety, language aptitude, and intelligence. Motivation is further classified in Gardner's socioeducation model into effort, desire, and affect. Effort refers to the time and zeal the learner shows for SLA; desire shows the extent the learner wants to achieve proficiency in the target language; and affect indicates the learner's emotional responses to the target language.

Peters (2000) states that intelligence plays less important role than appropriate priorities and behavior. If a student is intrinsically motivated, he/she will show better results. Lumsden (n.d.) considers intrinsic motivation as the zeal of the student for learning. Such a student takes delight in language learning, as to him the course content is rewarding and interesting.

There are various techniques on part of the teacher to improve the intrinsic motivation of their students. Harris (1991) believes that the language teacher should give detailed explanation of each lesson for a better understanding of the students. Harris further says that a caring teacher can enhance their students' intrinsic motivation. Similarly, Lumsden (op. cit.) also stresses on the fact that when the 
students feel that the language teacher is helpful and cooperative, they will yield good results. In addition, Bantjes (1994) asserts that parental awareness is crucial to a learner's motivation. Learning environment can only be made conducive if the student is facilitated both at home and school/college.

Falk (1978) asserts that successful learners of second language are those who like the target language speakers and their culture. In this connection Finegan (1999) theorizes that "integrative motivation typically underlies successful acquisition of a wide range of registers and a native like pronunciation" ( $p 568$ ).

On the other hand instrumental motivation, according to Hudson (2000), refers to the utilitarian and practical form of the study of a second language, such as applying for a job, translating, or achieving higher rank, to mention a few.

Despite the fact that both the integrative and instrumental motivations are considered as crucial in SLA, studies show that integrative motivation sustains the learner's long-term success in SLA (Taylor, Meynard and Rheault 1977; Ellis 1997; Crookes et al, 1991), though in India, second language learners are often successful with instrumental purposes. He gives the example of India where English has gained the status of an international language.

\section{Extrinsic Motivation}

Extrinsic or external motivation refers to the encouraging and friendly attitude of the teachers and of the parents towards the learner. It is necessary for a language teacher that $\mathrm{s} /$ he should try his/her level best to motivate students for leaning the target language, as Dornyei (2001) puts that "teacher's skills in motivating learners should be seen as central to teaching effectiveness". The word "central" is noteworthy, because the teacher's talent and command of the target language are futile if he/she cannot motivate the class.

In order to understand the teacher-students relationship, it is necessary to explain the power relationship among the people who group together. In this regard Wright (1987) says that there is a certain power relationship established among people when they group together. He classifies this power relationship into three different types: coercive; reward-based; and referent. Coercive power is based on punishment; the second type is based on reward while referent is based on motivation. Among the aforementioned types of power relationship, motivation plays the most influential role in learning. In this connection Argyle, 1969) maintains that a group goes through the following four stages which have beneficial pedagogical implications in an actual classroom environment. These four stages are: Forming; storming; norming; and performing. In the forming stage the group members are a bit anxious, as they feel dependent on the leader/teacher. The forming stage is followed by the storming stage where some misunderstanding is created and consequently the group members resist their leader. At the norming stage a cooperative environment is created among the group members. They start 
sharing their feelings and views. The last stage is performing where the group members resolve their problems and start working efficiently in their respective capacities.

Daniel (1994) asserts that nearly all sorts of groups go through these stages. He further states that students also go through these stages that is why there are always some sort of hindrances in the smooth flow of teaching-learning process in the beginning.

The learners of English as a second language need to be motivated and encouraged for the process of learning the language. In this regard Lin (2000) in his article, Personalizing Language Learning in Large Classes asserts that in order to find out the students' interest, the language teacher should encourage them. The students should be given opportunity to talk in English about topics of their own interest. In this way they can easily enhance their spoken competency.

The factor of motivation in SLA is further emphasized by Hussin, et al (2001). In conclusion to Sustaining an Interest in Learning English and Increasing the Motivation to Learn English: An Enrichment Program they maintain that language teaching in rural areas remains a great challenge. In the rural as student's performance is judged by the written examination rather than by communicative proficiency. They further stress on the importance of motivation and add that teachers should encourage students. Moreover, the teachers should use the latest teaching techniques. Thus Hussain et al consider student-centered and task-based techniques as the best way to enhance second language acquisition, though they do not give a detailed account of the various modern techniques of language teaching.

In order to control the classroom environment for better results a language teacher must devise various strategies. Reward and punishment are not the only things to be deemed necessary for teaching-learning process. That is why Dornyei (2001) asserts that "the spectrum of other potentially more effective motivational strategies is so broad that it is hard to imagine that none of them would work." In addition, the language teacher plays an important role in motivating his/her students. The teacher can attract the students' attention towards language learning. (Emily (2002) considers humour an effective tool in language teaching in a second language classroom. It creates an effective environment in the SLC. Thus when students are positively reinforced, they show better results. Kristmanson (2000) further emphasizes the need to create an effective environment in the SLC. He maintains that if a student is motivated and is put in an environment that lowers his anxiety, s/he will feel relaxed and improve his/her language skills. In contrast, if a student feels threatened and intimidated, s/he will yield less satisfactory feedback. On the other hand if the teacher keeps his/her class tense, the students will be discouraged and they will consequently shun improving language skills (MacIntyre, 1999 and Young, 1999).In addition, Good and Brophy (1994) assert that it is necessary for a language teacher to create a relaxed atmosphere in the classroom in order to motivate his/her students. They further say that students who feel alienated in the classroom will achieve less proficiency. Moreover, there should be relevance 
of the content to the learners' need and desire (Chamber, 1999). It sometimes becomes very much difficult to design a course content that caters to the needs of all students, especially in the colleges of Khyber Pakhtunkhwa where the English course content at intermediate level is designed for multiple disciplines such as premedical, pre-engineering, arts and humanities, D.Com, etc.

Learners' motivation can be enhanced by encouraging them. In this connection Dornyei (2001) suggests that a language teacher can easily enhance his/her students' self-confidence by minimizing the anxiety of the class through less stressful learning context and by giving the tasks in which every student can participate. Moreover, Fear can be minimized through the teacher's encouragement of his/her students. Karen Bordonaro (1999) considers encouragement as a guiding principle in L2 learning. She says that in case the students are given a minimal amount of suggestions and direction, they produce very good papers and oral reports on topics of their own choice. In this way, the students have an opportunity to help each other in their selected areas by peer reviewing and commenting. This creates a sense of positive goodwill among the students.

In an SLA classroom, the language teacher needs to be neither too strict nor too lenient. Stephen B. Ryan (2011) explains this complex teaching phenomenon that on one hand the language teacher should be polite and friendly so that the students may not feel threatened, but on the other the same teacher should be strict regarding daily attendance and regularity. This duality creates great confusion for the language teacher as to be friendly and strict at the same time.

Moreover, the second language pedagogy is one of the most important factors in an SLA classroom. In his The Functions of Teachers' Code Switching, Sert (2005) considers code switching an effective tool in an ESL class, though the teacher is not always conscious of using this tool. The direct method does not always work. There are certain concepts and cultural terminology that puzzle the learners. Such a difficulty is resolved through jumping into the mother tongue of the learner. Sert further quotes Mattson that code switching serves various functions such as "topic switch, affective functions, and repetitive functions.

\section{Material and Methods}

The present research was exploratory. The researchers had no hypotheses beforehand, so he wanted to explore the strength of the different factors under study. A survey was conducted through questionnaire for the purpose of collecting information from the respondents as to what extent the factors understudy were involved in English learning of the intermediate level students in government colleges in District Bannu.

For the present study, Likert scale questionnaire was selected. Thus, an agreement-scale questionnaire was prepared and distributed among the respondents in order to explore the extent in percentage of the factors understudy. Likert scale 
questionnaire was selected for data collection as it had a five-option scale which gave ample room for the respondents to choose. The options of Strongly Agree and Agree were combined and considered as Agree. Similarly, Disagree and Strongly Disagree were combined and considered as Disagree. The Undecided were considered as null and void, hence they were not included in the analysis.

The questionnaire was divided into four facets corresponding to the four factors understudy, i.e. Intrinsic Motivation, Extrinsic Motivation, Parents' Income, and Parents' Education. Each facet contained ten statements. The statements were written in such a way that they indirectly give the scholar an insight into the extent of the influence of the factors understudy. The facet of Parents' Education contained statements the response to which shows the level of awareness of the parents towards their children's learning of English.

The questionnaire was first distributed among twenty respondents of Government Post Graduate College, Bannu other than the sample colleges. They were allowed to ask questions freely in case they did not understand. Keeping in view their comments, the questionnaire was modified.

After collecting the questionnaires from the respondents, the data were tabulated in MS Excel. Then the data were analyzed using SPSS and the range and percentage of the responses were found out. The data were, then, interpreted in the light of the research objectives.

A table was drawn for the analysis of each statement. Similarly each table is interpreted as well. Moreover, for each facet (containing 10 tables) a 3 - D Column was drawn in order to have a compact view of all the ten statements of each facet that were analyzed in the tables. Apart from it two Exploded Pi-Charts were drawn for showing the average percentage response to all the four factors understudy separately.

\section{Results and Discussion}

This section of the paper contains the comprehensive study of the primary data collected from the intermediate level students through questionnaire. The questionnaire is divided into two facets consisting in ten statements each. Every statement is examined both in the form of a table as well as graph. Frequency refers to the number of occurrence of the individual scale item. Percentage shows the percentage of each scale item. $S A+A \%$ indicates the combination of strongly agree and agree percentages. Similarly, $D+S D \%$ shows the combination of disagree and strongly disagree percentages. The Undecided are not included in the analysis. Moreover, Total refers to the total number and percentage response of respondents in the Frequency and Percentage columns respectively. For each table the table number is given. The table number is followed by the table caption. After each graph the analysis is given. At the end a 3 - D Column is drawn showing all ten statements. Moreover, exploded Pi-charts are given for showing the average agree and disagree percentage of the respondents. 


\section{Intrinsic Motivation}

Table 1

English Liking

\begin{tabular}{ccccc}
\hline Statement & Scale & Frequency & Percentage & SA+A \% \\
\hline & SA & 12 & 12 & \multirow{2}{*}{28} \\
\cline { 2 - 4 } & $\mathrm{A}$ & 16 & 16 & \\
\cline { 2 - 4 } I like English. & $\mathrm{U}$ & 3 & 3 & $\mathrm{D}+\mathrm{SD} \%$ \\
\cline { 2 - 4 } & $\mathrm{D}$ & 38 & 38 & 69 \\
\cline { 2 - 4 } & $\mathrm{SD}$ & 31 & 31 & \\
\hline Total & & 100 & 100 & \\
\hline
\end{tabular}

Table 1 indicates that $69 \%$ of the total respondents disagreed and $28 \%$ agreed that they like English.

Table 2

English Skills and Good Job

\begin{tabular}{|c|c|c|c|c|}
\hline Statement & Scale & Frequency & Percentage & $\mathrm{SA}+\mathrm{A} \%$ \\
\hline \multirow{5}{*}{$\begin{array}{l}\text { It is difficult to find a good } \\
\text { job without having good } \\
\text { English skills }\end{array}$} & SA & 10 & 10 & \multirow{2}{*}{22} \\
\hline & A & 12 & 12 & \\
\hline & $\mathrm{U}$ & 7 & 7 & $\mathrm{D}+\mathrm{SD} \%$ \\
\hline & D & 36 & 36 & 71 \\
\hline & SD & 35 & 35 & \\
\hline Total & & 100 & 100 & \\
\hline
\end{tabular}

Table 2 describes that $71 \%$ of the total respondents disagreed and $22 \%$ agreed that it is difficult to find a good job without having good English skills.

Table 3

Interest

\begin{tabular}{cccccc}
\hline Statement & Scale & Frequency & Percentage & SA+A \% \\
\cline { 2 - 4 } & $\mathrm{SA}$ & 8 & 8 & \multirow{2}{*}{25} \\
\cline { 2 - 5 } English is interesting. & $\mathrm{A}$ & 17 & 17 & \\
\cline { 2 - 5 } & $\mathrm{U}$ & 10 & 10 & \multirow{2}{*}{$\mathrm{D}+\mathrm{SD} \%$} \\
\cline { 2 - 4 } & $\mathrm{D}$ & 38 & 38 & \multirow{2}{*}{65} \\
\cline { 2 - 4 } & $\mathrm{SD}$ & 27 & 27 & \\
\hline Total & & 100 & 100 & \\
\hline
\end{tabular}

Table 3 mentions that $65 \%$ of the total respondents disagreed and $25 \%$ agreed that English is interesting. 
Table 4

Multilingual

\begin{tabular}{ccccc}
\hline \multirow{2}{*}{ Statement } & Scale & Frequency & Percentage & SA+A \% \\
\hline & $\mathrm{SA}$ & 6 & 6.0 & \multirow{2}{*}{22} \\
\cline { 2 - 4 } & $\mathrm{A}$ & 16 & 16.0 & \\
\cline { 2 - 4 } I want to be multilingual. & $\mathrm{U}$ & 12 & 12.0 & \multirow{2}{*}{$\mathrm{D}+\mathrm{SD} \%$} \\
\cline { 2 - 4 } & $\mathrm{D}$ & 30 & 30.0 & \multirow{2}{*}{66} \\
\cline { 2 - 4 } & $\mathrm{SD}$ & 36 & 36.0 & \\
\hline Total & & 100 & 100 & \\
\hline
\end{tabular}

Table 4 indicates that $66 \%$ of the total respondents disagreed and $22 \%$ agreed that they want to be multilingual.

Table 5

Need of the day

\begin{tabular}{ccccc}
\hline \multirow{2}{*}{ Statement } & Scale & Frequency & Percentage & \multirow{2}{*}{ SA+A \% } \\
\hline & SA & 9 & 9 & \multirow{2}{*}{25} \\
\cline { 2 - 4 } English is the need of the day & $\mathrm{A}$ & 16 & 16 & \\
\cline { 2 - 4 } & $\mathrm{U}$ & 12 & 12 & $\mathrm{D}+\mathrm{SD} \%$ \\
\cline { 2 - 4 } & $\mathrm{D}$ & 28 & 28 & \multirow{2}{*}{63} \\
\hline Total & $\mathrm{SD}$ & 35 & 35 & \\
\hline
\end{tabular}

Table 5 describes that $63 \%$ of the total respondents disagreed and $25 \%$ agreed that English is the need of the day.

Table 6

Modern Technology and English

\begin{tabular}{ccccc}
\hline Statement & Scale & Frequency & Percentage & SA+A \% \\
\hline & SA & 9 & 9 & \multirow{2}{*}{21} \\
\cline { 2 - 4 } & $\mathrm{A}$ & 12 & 12 & \\
\cline { 2 - 4 } $\begin{array}{c}\text { English learning is necessary } \\
\text { for utilizing modern } \\
\text { technology. }\end{array}$ & $\mathrm{U}$ & 12 & 12 & $\mathrm{D}+\mathrm{SD} \%$ \\
\cline { 2 - 4 } & $\mathrm{D}$ & 39 & 39 & \multirow{2}{*}{67} \\
\hline Total & & 28 & 28 & \\
\hline
\end{tabular}

Table 6 mentions that $67 \%$ of the total respondents disagreed and $21 \%$ agreed that English learning is necessary for utilizing modern technology.

Table 7

Belief about English Speaking

\begin{tabular}{|c|c|c|c|c|}
\hline Statement & Scale & Frequency & Percentage & $\mathrm{SA}+\mathrm{A} \%$ \\
\hline \multirow{5}{*}{$\begin{array}{l}\text { I believe that one day I shall } \\
\text { be able to speak English } \\
\text { fluently. }\end{array}$} & SA & 15 & 15 & \multirow{2}{*}{26} \\
\hline & A & 11 & 11 & \\
\hline & U & 8 & 8 & $\mathrm{D}+\mathrm{SD} \%$ \\
\hline & $\mathrm{D}$ & 37 & 37 & \multirow{2}{*}{66} \\
\hline & SD & 29 & 29 & \\
\hline Total & & 100 & 100 & \\
\hline
\end{tabular}

Table 7 indicates that $66 \%$ of the total respondents disagreed and $26 \%$ agreed that they believe that one day they shall be able to speak English fluently. 
Table 8

Listening to News

\begin{tabular}{|c|c|c|c|c|}
\hline Statement & Scale & Frequency & Percentage & $\mathrm{SA}+\mathrm{A} \%$ \\
\hline \multirow{5}{*}{$\begin{array}{c}\text { I listen to news in English in } \\
\text { order to improve my } \\
\text { English. }\end{array}$} & SA & 9 & 9 & \multirow{2}{*}{19} \\
\hline & $\mathrm{A}$ & 10 & 10 & \\
\hline & $\mathrm{U}$ & 13 & 13 & $\mathrm{D}+\mathrm{SD} \%$ \\
\hline & $\mathrm{D}$ & 35 & 35 & \multirow{2}{*}{68} \\
\hline & SD & 33 & 33 & \\
\hline Total & & 100 & 100 & \\
\hline
\end{tabular}

Table 8 describes that $68 \%$ of the total respondents disagreed and 19\% agreed that they listen to news in English in order to improve their English.

Table 9

Watching Movies

\begin{tabular}{|c|c|c|c|c|}
\hline Statement & Scale & Frequency & Percentage & $\mathrm{SA}+\mathrm{A} \%$ \\
\hline \multirow{5}{*}{$\begin{array}{l}\text { I watch movies to improve } \\
\text { my listening and speaking } \\
\text { skills. }\end{array}$} & SA & 15 & 15 & \multirow{2}{*}{25} \\
\hline & $\mathrm{A}$ & 10 & 10 & \\
\hline & $\mathrm{U}$ & 9 & 9 & $\mathrm{D}+\mathrm{SD} \%$ \\
\hline & $\mathrm{D}$ & 37 & 37 & \multirow{2}{*}{66} \\
\hline & SD & 29 & 29 & \\
\hline Total & & 100 & 100 & \\
\hline
\end{tabular}

Table 9 mentions that $66 \%$ of the total respondents disagreed and $25 \%$ agreed that they watch movies to improve their listening and speaking skills.

Table 10

Reading Stories

\begin{tabular}{ccccc}
\hline Statement & Scale & Frequency & Percentage & SA+A \% \\
\hline & SA & 9 & 9 & \multirow{2}{*}{27} \\
\cline { 2 - 4 } & $\mathrm{A}$ & 18 & 18 & \multirow{2}{*}{$\begin{array}{c}\text { D } \\
\text { I read novels and short } \\
\text { stories to improve my }\end{array}$} \\
\cline { 2 - 4 } reading and writing skills. & $\mathrm{U}$ & 13 & 13 & \multirow{2}{*}{60} \\
\cline { 2 - 4 } & $\mathrm{D}$ & 30 & 30 & \\
\hline Total & $\mathrm{SD}$ & 30 & 30 & \\
\hline
\end{tabular}

Table 10 indicates that $60 \%$ of the total respondents disagreed and $27 \%$ agreed that they read novels and short stories to improve their reading and writing skills. 


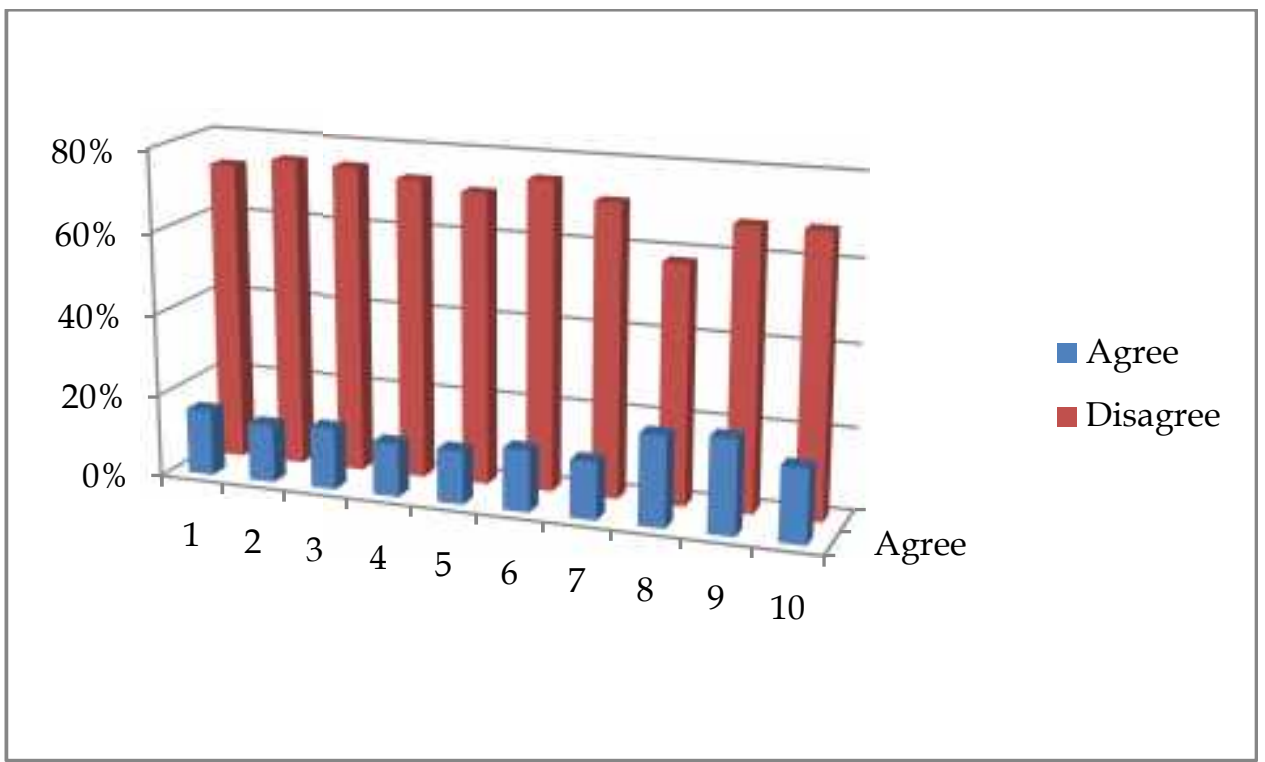

The 3D column shows all the ten statements with the respective Agree and Disagree percentages.

\section{Extrinsic Motivation}

Table 11

Teacher and English

\begin{tabular}{cccccc}
\hline Statement & \multicolumn{2}{c}{ Scale } & Frequency & Percentage & \multirow{2}{*}{ SA+A $\%$} \\
\hline & SA & 7 & 7 & \multirow{2}{*}{18} \\
\cline { 2 - 4 } & $\mathrm{A}$ & 11 & 11 & \\
\cline { 2 - 4 } My class teacher speaks & $\mathrm{U}$ & 10 & 10 & $\mathrm{D}+\mathrm{SD} \%$ \\
\cline { 2 - 4 } English in the class. & $\mathrm{D}$ & 36 & 36 & \multirow{2}{*}{72} \\
\cline { 2 - 4 } & $\mathrm{SD}$ & 36 & 36 & \\
\hline Total & & 100 & 100 & \\
\hline
\end{tabular}

Table 11 describes that $72 \%$ of the total respondents disagreed and $18 \%$ agreed that their class teachers speak English in the class.

Table 12

Teachers' Fluency

\begin{tabular}{|c|c|c|c|c|}
\hline Statement & Scale & Frequency & Percentage & $\mathrm{SA}+\mathrm{A} \%$ \\
\hline \multirow{5}{*}{$\begin{array}{l}\text { The teachers' pronunciation } \\
\text { is impressive. }\end{array}$} & SA & 7 & 7 & \multirow{2}{*}{16} \\
\hline & $\mathrm{A}$ & 9 & 9 & \\
\hline & $\mathrm{U}$ & 12 & 12 & $\mathrm{D}+\mathrm{SD} \%$ \\
\hline & $\mathrm{D}$ & 35 & 35 & \multirow{2}{*}{72} \\
\hline & SD & 37 & 37 & \\
\hline
\end{tabular}


Table 12 mentions that $72 \%$ of the total respondents disagreed and $16 \%$ agreed that their teachers' pronunciation is impressive.

Table 13

Importance of English

\begin{tabular}{|c|c|c|c|c|}
\hline Statement & Scale & Frequency & Percentage & $\mathrm{SA}+\mathrm{A} \%$ \\
\hline \multirow{5}{*}{$\begin{array}{l}\text { The teacher stresses on the } \\
\text { importance of English in the } \\
\text { modern world. }\end{array}$} & SA & 3 & 3 & \multirow{2}{*}{15} \\
\hline & A & 12 & 12 & \\
\hline & $\mathrm{U}$ & 14 & 14 & $\mathrm{D}+\mathrm{SD} \%$ \\
\hline & D & 38 & 38 & \multirow{2}{*}{71} \\
\hline & SD & 33 & 33 & \\
\hline Total & & 100 & 100 & \\
\hline
\end{tabular}

Table 13 indicates that $71 \%$ of the total respondents disagreed and $15 \%$ agreed that their teachers stress on the importance of English in the modern world.

Table 14

Teaching Techniques

\begin{tabular}{|c|c|c|c|c|}
\hline Statement & Scale & Frequency & Percentage & $\mathrm{SA}+\mathrm{A} \%$ \\
\hline \multirow{5}{*}{$\begin{array}{l}\text { The teacher uses different } \\
\text { techniques to make us learn } \\
\text { the lessons. }\end{array}$} & SA & 6 & 6 & \multirow{2}{*}{19} \\
\hline & A & 13 & 13 & \\
\hline & $\mathrm{U}$ & 13 & 13 & $\mathrm{D}+\mathrm{SD} \%$ \\
\hline & $\mathrm{D}$ & 39 & 39 & \multirow{2}{*}{68} \\
\hline & SD & 29 & 29 & \\
\hline Total & & 100 & 100 & \\
\hline
\end{tabular}

Table 14 describes that $68 \%$ of the total respondents disagreed and $19 \%$ agreed that their teachers use different techniques to make them learn the lessons.

Table 15

Teacher's Attitude

\begin{tabular}{|c|c|c|c|c|}
\hline Statement & Scale & Frequency & Percentage & $\mathrm{SA}+\mathrm{A} \%$ \\
\hline \multirow{5}{*}{$\begin{array}{l}\text { The teacher does not take us } \\
\text { to task when we commit } \\
\text { mistakes. }\end{array}$} & SA & 6 & 6 & \multirow{2}{*}{14} \\
\hline & A & 8 & 8 & \\
\hline & $\mathrm{U}$ & 13 & 13 & $\mathrm{D}+\mathrm{SD} \%$ \\
\hline & $\mathrm{D}$ & 42 & 42 & \multirow{2}{*}{73} \\
\hline & SD & 31 & 31 & \\
\hline Total & & 100 & 100 & \\
\hline
\end{tabular}

Table 15 indicates that $73 \%$ of the total respondents disagreed and $14 \%$ agreed that their teachers do not take them to task when they commit mistakes.

Table 16

Encouragement

\begin{tabular}{ccccc}
\hline Statement & Scale & Frequency & Percentage & SA+A \% \\
\hline & SA & 9 & 9 & \multirow{2}{*}{20} \\
\cline { 2 - 4 } $\begin{array}{c}\text { The teacher encourages us } \\
\text { when we try to speak }\end{array}$ & $\mathrm{A}$ & 11 & 11 & \multirow{2}{*}{$\mathrm{U}$} \\
\cline { 2 - 5 } & & 12 & 12 & $\mathrm{D}+\mathrm{SD} \%$ \\
\hline
\end{tabular}




\begin{tabular}{ccccc}
\hline English. & $\mathrm{D}$ & 41 & 41 & \multirow{2}{*}{68} \\
\cline { 2 - 4 } & $\mathrm{SD}$ & 27 & 27 & \\
\hline Total & & 100 & 100 \\
\hline
\end{tabular}

Table 4.2 .6 mentions that $68 \%$ of the total respondents disagreed and $20 \%$ agreed that their teachers encourage them when they try to speak English.

Table 17

Telling Jokes

\begin{tabular}{|c|c|c|c|c|}
\hline Statement & Scale & Frequency & Percentage & $\mathrm{SA}+\mathrm{A} \%$ \\
\hline \multirow{5}{*}{$\begin{array}{l}\text { The teacher makes the class } \\
\text { lively by telling jokes. }\end{array}$} & SA & 12 & 12 & \multirow{2}{*}{18} \\
\hline & A & 6 & 6 & \\
\hline & $\mathrm{U}$ & 11 & 11 & $\mathrm{D}+\mathrm{SD} \%$ \\
\hline & $\mathrm{D}$ & 41 & 41 & \multirow{2}{*}{70} \\
\hline & SD & 29 & 29 & \\
\hline Total & & 100 & 100 & \\
\hline
\end{tabular}

Table 17 describes that $70 \%$ of the total respondents disagreed and $18 \%$ agreed that their teachers make the classes lively by telling jokes.

Table 18

Interesting Lessons

\begin{tabular}{ccccc}
\hline Statement & Scale & Frequency & Percentage & SA+A $\%$ \\
\hline & SA & 4 & 4 & \multirow{2}{*}{15} \\
\cline { 2 - 4 } & $\mathrm{A}$ & 11 & 11 & \\
\cline { 2 - 4 } $\begin{array}{c}\text { The lessons in the course } \\
\text { book are interesting. }\end{array}$ & $\mathrm{U}$ & 12 & 12 & D+SD $\%$ \\
\cline { 2 - 4 } & $\mathrm{D}$ & 38 & 38 & \multirow{2}{*}{74} \\
\hline Total & & 35 & 35 & \\
\hline
\end{tabular}

Table 18 indicates that $74 \%$ of the total respondents disagreed and $15 \%$ agreed that the lessons in the course book are interesting.

Table 19

\section{College Library}

\begin{tabular}{ccccc} 
Statement & Scale & Frequency & Percentage & \multirow{2}{*}{ SA+A $\%$} \\
\hline & SA & 6 & 6 & \multirow{2}{*}{20} \\
\cline { 2 - 4 } & $\mathrm{A}$ & 14 & 14 & \\
\cline { 2 - 4 } $\begin{array}{c}\text { The college library is open } \\
\text { for us throughout. }\end{array}$ & $\mathrm{U}$ & 9 & 9 & $\mathrm{D}+\mathrm{SD} \%$ \\
\cline { 2 - 4 } & $\mathrm{D}$ & 25 & 25 & \multirow{2}{*}{71} \\
\hline TD & 46 & 46 & \\
\hline Total & & 100 & 100 & \\
\hline
\end{tabular}

Table 19 mentions that $71 \%$ of the total respondents disagreed and $20 \%$ agreed that the college libraries are open for them throughout. 
Table 20

Necessary Tips

\begin{tabular}{|c|c|c|c|c|}
\hline Statement & Scale & Frequency & Percentage & $\mathrm{SA}+\mathrm{A} \%$ \\
\hline \multirow{5}{*}{$\begin{array}{l}\text { The teacher gives us } \\
\text { necessary tips to improve } \\
\text { language skills. }\end{array}$} & SA & 4 & 4 & \multirow{2}{*}{16} \\
\hline & $\mathrm{A}$ & 12 & 12 & \\
\hline & $\mathrm{U}$ & 13 & 13 & $\mathrm{D}+\mathrm{SD} \%$ \\
\hline & $\mathrm{D}$ & 33 & 33 & \multirow{2}{*}{71} \\
\hline & SD & 38 & 38 & \\
\hline Total & & 100 & 100 & \\
\hline
\end{tabular}

Table 20 describes that $71 \%$ of the total respondents disagreed and $16 \%$ agreed that the teachers tell them necessary tips to improve language skills.

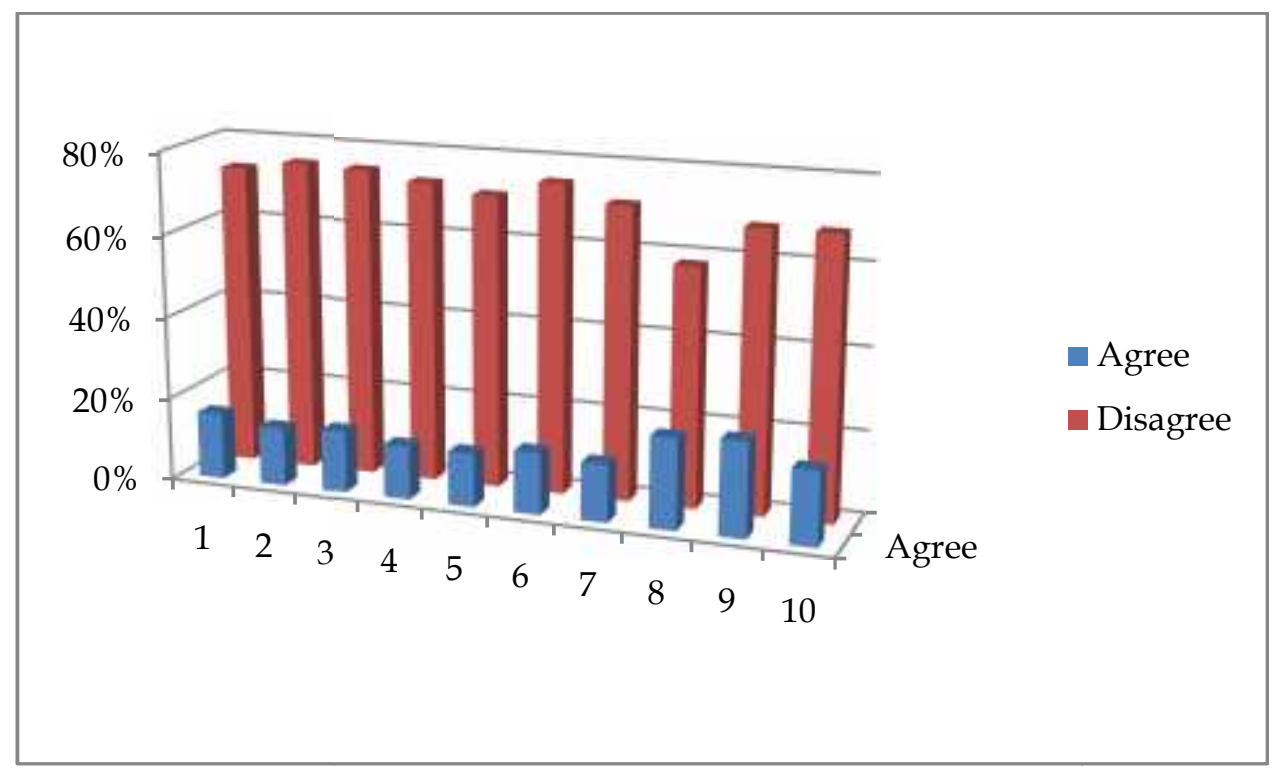

The 3D column shows all the ten statements with the respective Agree and Disagree percentages.

\section{Conclusion}

On the basis of the analysis in the Data Analysis findings of each factor were drawn. The percentage of the agreement is lower than that of disagreement throughout.

\section{Intrinsic Motivation}

The analyzed data show that majority of the students were not intrinsically motivated. All of the ten statements were designed in such a way that agreement to them showed the extent of intrinsic motivation. But the students showed more disagreement than agreement which clearly indicates that they were less intrinsically 
motivated. The conclusions drawn on the basis of the findings with respect to intrinsic motivation are as follows.

Majority of the students do not like English and they do not think that it is difficult to find a good job without having good English skills. This is so because majority of the respondents do not consider English learning as the need of the day. Moreover, most of the students disagreed that they believe that one day they shall be able to speak fluently. Most of them neither listen to news nor watch movies to improve their listening and speaking skills. Similarly, majority of the students disagreed that they read novels and short stories to improve their reading and writing skills.

\section{Extrinsic Motivation}

The analyzed data show that majority of the respondents/students were not extrinsically motivated. The statements were designed in such a way that agreement to them showed the extent of extrinsic motivation. But the students showed more disagreement than agreement which clearly indicates that they were less extrinsically motivated. Following are the conclusions drawn on the basis of the findings with respect to extrinsic motivation.

Majority of the class teachers do not speak English in the class. Similarly, most of the teachers do not stress the importance of English in the modern world. Again, majority of the teachers do not use modern techniques to make their students learn the lessons. Apart from it most of the teachers chide the students whenever they commit mistakes. In addition, majority of the teachers do not encourage their students when they try to speak English. Similarly, in most cases the college library is not open to the students for reading newspapers and other useful books. 


\section{References}

Argyle, M. (1969). Social interaction. London: Tavistock Press.

Awan, A. R. (2008).Factors hampering the learning and speaking of English in Pakistanisociety.NUML Research Magazine, NUML Press, Islamabad, 11/o8.

Bordonaro, K. (1999).Encouragement. The Internet TESL Journal, Vol. V, No. 9.

Chomsky, N. (1965).Aspects of the theory of syntax. Cambridge, MA: MIT Press. In MacWhinney, B. (2001). Models of second language acquisition. In P. Robinson (Ed.).Krashen, Stephen. (1981). “The Fundamental Pedagogical Principle in Second Language Teaching"Studia Linguistica35: 50-70. http://www.li.suu.edu

Crookes, G., \& Schmidt R.W. (1991). Motivation: Reopening the research agenda. Language learning, 41(4), 469-512.

Daniels, R. (1994). Motivational Mediators of Cooperative Learning. Psychological Reports, 74: 1011-22.

Dornyei, Z. and Otto, I. (1998). Motivation in action: A process model of L2 motivation. Working Papers in Applied Linguistics (London: Thames Valley University), 4: 43-69.

Egger, Paul. (1987).Guided oral discourse for beginners: What for and how to? "English Teaching Forum", 25/3.

Ellis, R. (1997).The study of second language acquisition. Oxford University Press.

Emily. P. (2002). Humour. The Internet TESL Journal, Vol. VIII, No. 3.

English and Increasing the Motivation to Learn English: An Enrichment Program. The Internet TESL Journal, Vol. VII, No. 5.

Oxford English Dictionary.2nd ed. (1989). OED. Online. Oxford University Press.

Falk, J. (1978). Linguistics and language: A survey of basic concepts and implications(2nd ed.). John Wiley and Sons

Finegan, E. (1999). Language : Its structure and use (3rd ed.). Harcourt Brace.

Gardner,R.C. (1982) Language attitudes and language learning. In E. Bouchard Ryan \& H. Davis,G.B. (1993).Tools for teaching. Jossey-Bass Publishers: San Francisco.

Giles, H., \& Coupland, N. (1991).Language: Contexts and consequences. Open University Press. 
Good, T. L. and Brophy, J. E. (1994).Looking in classrooms. 6 th edition. New York: HarperCollins.

Harris, Robert. (1991). Some ideas for motivating students. Virtual Salt.

Hussain, S. Maarof, N. D'Cruz, J.V. (2001).Sustaining an Interest in Learning English and Increasing the Motivation to Learn English: An Enrichment Program. The Internet TESL Journal, Vol. VII, No. 5.

Hudson, G. (2000).Essential introductory linguistics. Blackwell Publishers

Hussain, S. Maarof, N. D'Cruz, J.V. (2001).Sustaining an Interest in Learning iteslj.org/Techniques/Hussin-Motivation/

Kristmanson, P. (2000). Affect: in the Second Language Classroom: How to create an emotional climate. Reflexions, 19, (2), 1-5. http://iteslj.org.

Larsen-Freeman, D., Long. M. H. (1991).An introduction to second language acquisition Research. New York: Longman.

Lin,C-C. (2002).Personalising language learning in large classes. http://comp.uark.edu/ cxl11/web/

Long, M. H. (1996).The role of the linguistic environment in second language acquisition. In W. Ritchie \& T. Bhatia (Eds.), Handbook of Second Language Acquisition.San Diego: Academic Press.

Lumsden, Linda S. (n.d.). Student's Motivation to Learn. ERIC Digest Number 92.

MacIntyre, P. D. (1999). Language anxiety: A review of the research for language Teachers. In Rogers, C. (1991).On becoming a person. Boston, MA: Houghton Mifflin.

Peter, Ruth. (2000). Overcoming Underachieving. Broadway Books.

Ryan, B. S. (2001). Overcoming Common Problems Related to Communicative Methodology. The Internet TESL Journal, Vol. VII, No. 11. http://iteslj.org.

Sert, Oclay. (2005).The Functions of Teachers' Cozaaaade Switching, The Internet TESL Journal, Vol.xi, No.8.

Taylor, D.M. (1997). Meynard, R., \& Rheault, E. Threat to ethnic identity and secondlanguage learning. In $\mathrm{H}$. Giles, Language, ethnicity and intergroup relations (pp. 99-118). Academic Press.

Wright, T. (1987). Roles of Teachers \& Learners. Oxford: Oxford University Press 